\title{
Erratum to: The Compatibility of Relevance and Mingle
}

\section{José M. Méndez}

Published online: 5 May 2010

(C) Springer Science+Business Media, B.V. 2010

Erratum to: J Philos Logic (1988) 17:279-297 DOI 10.1007/BF00247955

In Section 9 of the original paper, a set of matrices is defined. Now, there are three misprints in this set, to wit, where it reads

$$
\begin{gathered}
+1 \rightarrow-2=-2 \\
+0 \vee-2=+2 \\
+0 \vee-1=+1
\end{gathered}
$$

it should read, respectively,

$$
\begin{gathered}
+1 \rightarrow-2=-3 \\
+0 \vee-2=-2 \\
+0 \vee-1=-1
\end{gathered}
$$

The online version of the original article can be found at http://dx.doi.org/10.1007/BF00247955.

J. M. Méndez $(\bowtie)$

Edificio FES, Universidad de Salamanca, Campus Unamuno, 37007 Salamanca, Spain

e-mail: sefus@usal.es 